\title{
DEVELOPMENT OF INTERMODAL TRANSPORT AND LOGISTICS IN SERBIA
}

\author{
Snežana Tadić ${ }^{1}$, Slobodan Zečević ${ }^{2}$ \\ 1,2 University of Belgrade, Faculty of Transport and Traffic Engineering, Vojvode Stepe 305, 11000 \\ Belgrade, Serbia
}

Received 18 September 2012; accepted 23 October 2012

\begin{abstract}
Freight transport and logistics play a key role in economic and social terms by ensuring the competitiveness, economic growth and employment. Intermodal transport has received an increased attention due to problems of road congestion, environmental concerns and traffic safety. Strategic importance of speed, reliability and flexibility in the supply chain is forcing companies to re-examine traditional logistics services. As a result, interest in addressing the problem of intermodal transport and logistics is growing. In order to improve efficiency and sustainability of freight transport in Europe, the European Commission has launched a series of initiatives, projects and has defined the basic directions of development of intermodal transport and logistics. The paper presents the recommendations and measures for the further development of intermodal transport and logistics in Serbia.
\end{abstract}

Keywords: logistics, intermodal transport, logistics centers, network, development.

\section{Introduction}

Economic activity depends on the efficiency of logistics systems and processes along the supply chain. In the Action Plan for Freight Transport Logistics (EC, 2007c), logistics is defined as 'the oil in the EU's economic machine.' It is estimated that the share of the logistics industry in Europe is nearly 14\% of GDP. In the past few years, the logistics industry had growth rates above the average of European economies (EC, 2009b).

The most visible and environmentally most damaging part of the logistics is freight transport. Sustainability must become a key feature of freight transport and the European Union should devise policies that will facilitate this. The current EU approach towards the sustainability of freight transport and logistics is the promotion of intermodality and encourage wider and more effective use of ICT (Information and Communication Technology) in freight transport (EC, 2007a; EC, 2007b).

Globalization and the trend of increasing global trade and container transport encourage the growth of intermodal transport. Excluding disruptions to trade flows that have occurred 2008th and 2009th as a result of the global economic crisis, there has been significant growth in container flows. The total annual growth of container flows (in TEU) is about $10 \%$ in the period since 1997 by 2007 year. This growth is the logical consequence of increasing goods flows and processes of globalization.

\footnotetext{
${ }^{1}$ Corresponding author: s.tadic@sf.bg.ac.rs
} 
Trend of the first decade of the 21st century was to strengthen the traditionally strong intermodal connections, but also to the expansion of intermodal transport in the countries of Eastern Europe. The main measures for the development of intermodal transport in these countries are highlighted: modernization and development of intermodal infrastructure; innovative technologies; establishment of modern logistics centers.

The project "Facilitating Intermodal Transport in Serbia" was the support of the European Union for the long-term sustainable development of the logistics and intermodal transport in Serbia. The result of this project is a comprehensive feasibility study for the establishment of the logistics center in Belgrade. (EC, 2011) However, the logistics center in Belgrade should be seen as part of a network of terminals and logistics centers, whose development requires the implementation of specific measures and initiatives. The paper provides guidelines for efficient and long-term development of the logistics and intermodal transport in Serbia. The network of the logistics centers and intermodal terminals is an essential element of sustainable and longterm development.

\section{Recommendations and Measures for the Development of Intermodal Transport and Logistics}

In order to develop a logistics and intermodal transportation system it is necessary to establish and develop the intermodal transport network with logistics centers, which represent a modern connection of different modes and technologies of transportation. Logistics, multimodal transportation network has been largely developed in Europe. There are terminals with a developed infrastructure of maritime, rail, river and road transport in the region. Nevertheless, in Serbia and the region there are many disadvantages related to logistics and transport network, which represent limitation for the application of intermodal transport technologies.

The adoption and establishment of logistics center in Belgrade is a significant initiative of development of intermodal transport and logistics in Serbia and the region. However, for their successful development it is necessary to adopt and implement a series of priority and general recommendations and measures.

\subsection{The Priority Recommendations and Measures}

The priority recommendations and measures for the development of logistics and intermodal transportation in Serbia include:

- Establishment of logistic Association of Serbia and its inclusion in the work of international associations.

- Reorganization and intensification of the National Society for intermodal transport.

- Initiative for the formation of associations for logistics and intermodal transport on major corridors, transportation routes that connect Serbia with ports and commercial and transportation centers in the region.

- Intensification of work of promotional centre for the intermodal transport.

- Determination of micro location, structure and planning documents for the network of logistics centers and intermodal transport terminals in Serbia.

- Preparation of materials for the promotion and adoption of the concept of logistics and intermodal transportation (materials directed on the government, customers, stakeholders and potential investors).

- Organization of conferences, seminars and promotion of the thematic areas of the 
proposed concept of the logistics of Serbia (logistics network, intermodal transport chains, logistics partnership, etc.).

- Defining the curriculum for training in logistics and intermodal transport education with practice.

- Forming an information centre for logistics and intermodal transportation.

- Definition of fiscal and regulatory policy as a stimulus for the development of logistics and intermodal transportation.

- Formation of the Logistics Committee with members, representatives of public and private sector as the main advisory body to the Government of Serbia. The Committee would be responsible for the promotion and improvement of logistics and intermodal transportation.

- Preparation of legal and institutional framework for multimodal transport operators.

- Promotion of the intermodal transport system.

- Establishment of an integrator of multimodal transport as transport integrator that promotes, develops, and manages supply chains.

- Formation of project groups for the E-Logistics (IT infrastructure), H-Logistics (human resources and education), I-Logistics (logistics infrastructure), L-Logistics (legislation), M-Logistics (marketing and promotion), S-Logistics (support for small and medium enterprises - SMEs), ECO-Logistics (ecology and sustainable development) and C-Logistics (city logistics).

\subsection{The General Recommendations and Measures}

General recommendations and measures for the development of logistics and intermodal transportation in Serbia are related to the development of a network of logistics centers, intermodal terminals, the development of price competitiveness of certain modes of transport and transport technology, research and monitoring of commodity flows, the development of technical and technological solutions, development of cooperation and coordination in the transport, adopting and application of legislation, establishment of national associations and bodies, provision of the financial measures and support, etc.

Development of a network of logistics centers, terminals:

- Define the concept of a network of logistics centers and intermodal transport terminal in Serbia in terms of their location, structure, functions and status (international, regional, national or local);

- Build and complete the network of intermodal transport terminals;

- Ensure the implementation and harmonization of standards adopted at international level, according to an agreed development plan of multimodal European transport network;

- Ensure that the various national, regional and local plans include the development of intermodal terminals and logistics centers, as indispensable links in trade flows and logistics chains;

- Provide benefits when investing in the terminals, observing the rules on state support and competition;

- Finance focus on eliminating "bottlenecks" in the transport and logistics networks;

- Allocate public resources directly or indirectly in infrastructure to improve access to terminals and improve equipment for handling, storage and processing of intermodal cargo units (ITU);

- Affirm and continuously improve the implementation of intermodal transport technologies; 
- Apply benchmarking intermodal terminals and define a set of static and dynamic indicators of terminals with the aim of comparing, defining recommendations and establishing codes of best practice.

Development of the competitiveness price/costs of transport:

- Establish fair conditions for the market competition between different modes of transport (especially through the internalization of external costs), and provide the transparency of conditions competitiveness and cooperation within each form of transport;

- Encourage the development of cheaper and more efficient connection of the different modes of transport.

Research and monitoring of commodity flows:

- Systematic explore real market needs and requirements for technologies of intermodal transport;

- Continuously monitor and investigate characteristics of existing and potential cargo flows between the certain markets and regions;

- Take measures for the availability of clear and reliable statistical data;

- Regularly and as accurately as possible, record and monitor the "bottlenecks" that may endanger the development of intermodal transport;

- Take steps to ensure that all modes of transport have the same treatment in the combined transport market, by favoring, first of all, a better network connecting and at the same time developing new markets, particularly the introduction of competition between carriers;

- Continue the policy of liberalization of access to European transport routes under the condition of non-discrimination, harmonization and simplification of legislation and administrative procedures in this form of transportation;

- Promotion of intermodal transport technologies and specific intermodal transport chains;

- Support the development of information centers such as already established in some European countries, regions and ports;

- Support the creation of a comprehensive information centre for combined transport in order to ensure equal access to information to all interested users.

Development of technical and technological solutions:

- Take measures to improve the quality of logistics services through the use of modern technical and technological solutions transhipment, storage and transportation;

- Equip terminals with adequate infrastructure and equipment for handling of intermodal, logistics units;

- Support research, design and optimization in all parts of the logistics chain, either related to logistics, intermodal transport unit (ITU), the terminal or information systems;

- Ensure the compatibility of individual links in the multi-modal transport chain, with the aim to dimension the fleet to stay compatible with the infrastructure and intermodal transport units, regardless of the innovation;

- Implement the standards for cargo units, means of transport, transshipment and storage equipment;

- Apply modern telematic systems and information technology on the complete logistics chain;

- In order to improve the performance of logistics and intermodal chains and systems, and in consultation with stakeholders, to 
define a set of indicators to measure and monitor (such as sustainability, efficiency, etc.). The formation of a unified database promoted the transition to more efficient and cleaner transport modes and generally improved the logistic, intermodal performance.

Development of cooperation and coordination in logistics and transport:

- Develop the various cooperative relationships and partnerships between rail, road, maritime and river transportation and also between other participants in the logistics chain;

- Define and develop measures of coordination work of individual modes of transport, logistics centers and other important participants in the logistics chain;

- Develop the cooperative relationships with companies and customers;

- Define logistics strategy for the industry, within which are included: the identification of opportunities, methodologies and tools to implement logistics strategies and technologies of the intermodal transport in the field of logistic flows (supply logistics, production logistics, distribution logistics and reverse logistics). This strategic concept, because of specifics, should be defined for particular industries in the gravitational area of the intermodal network in Serbia, i.e.: agro-industry, energy, manufacturing materials, chemical industry, pharmaceutical industry, metal processing industry, etc.

Adoption and implementation of legislation:

- Define procedures and harmonize legislation, standards and documents in the multimodal transport chain;

- Consider the possibility of priority intermodal transport units in the field of international road transport;

- Liberalize the international combined transport, at least on a reciprocal basis, transport to the initial and final phase of road vehicles;

- Support all efforts towards the reduction, standardization and simplification of documents required for the regulation of combined transport;

- Improve regulations to carry out customs procedures and controls at the border and at places of loading and unloading (including veterinary and phyto-sanitary control) in order to accelerate the operation of combined transport and achieve shorter delivery time. Create reliable schedule of combined transport;

- Rigorously apply existing regulations in road transport, particularly regulations concerning driving and rest period of a driver, speed limits, weight and dimensions of vehicles, increase their control and apply appropriate penalties, to ensure greater road safety and fair competition in and between different modes of transport;

- Bring set of measures that will reduce the burden on road transport network.

Establishment and work of national associations and bodies:

- Intensify the National Society for intermodal transport, which will create a healthy institutional framework and conditions for the development and promotion of specific intermodal transport technologies;

- Establish a national association for logistics;

- Establish a national association of logistics centers and initiate inclusion in European association;

- Intensify the cooperation of scientific and professional institutions with business 
systems through planning, implementation and development of logistics strategies and intermodal transport technology;

- Develop cooperation with other national and international institutions and organizations relevant to the development of intermodal transport;

- Strengthen cooperation, both nationally and internationally, related to the coordination of environmental policy, land use and transport policies.

\section{Providing financial measures and support:}

- Facilitate, through financial and / or fiscal support, the initial purchase of transport equipment such as fleet and intermodal transport unit;

- Bring tax policy and define stimulating measures for the purchase of assets that will be used in intermodal transport (cargo units, vehicles, manipulative and related equipment);

- Define and adopt economic stimulus measures for the introduction and operation of intermodal transport chains;

- Approve funding for certain operating costs, and the first phase of new combined transport services, taking into account the current conditions and competition rules (until the implementation of cost internalization on transportation costs and taxes);

- Provide assistance in case of measures to improve efficiency and quality of combined transport services;

- Approve partial or total exemption from taxes, tolls and fees for the use of road infrastructure for vehicles engaged in the combined transport operations, particularly in the initial and final stages of transport that is carried by road vehicles;

- Attract private capital, which is, in any case, needed for development of logistics and combined transport.
Given that the proposed priority and general measures are initial activities in the promotion of logistics and intermodal transport in Serbia, in subsequent proceedings, with a greater degree of the detail should be processed certain topics and make action plans.

In cooperation with users and providers of logistics services, relevant ministries and state institutions should identify specific obstacles, problems and bottlenecks that hamper the implementation of logistics activities and intermodal transport technologies. On the other hand, they should define the relevant performance indicators and measures, as well as techniques to collect and update them for statistical purposes.

The prerequisite for successful implementation and development of intermodal transportation involves a change of behavior of all participants involved in the logistics chain. Many actors in the field of logistics and intermodal transportation lack professional staff. Expert Commission, in cooperation with relevant stakeholders, should prepare a list of minimum qualifications and training programs at different levels of specialization and to issue acknowledged certificates.

\section{The Network of Logistics Centers and Intermodal Transport Terminals}

Measures, solutions and priorities of development of logistics and intermodal transportation in the economic system of Serbia are linked to increasing market competitiveness of the economy and infrastructure and logistics networks and centers.

In order to increase market competitiveness, it is necessary to develop methodologies and tools to implement logistics strategies in the field of logistics flows (supply, production, distribution and return of materials and 
materials for recycling). It is necessary to form a database of the logistic performance of the logistics chains and logistics systems. On the other hand, the state should stimulate and support the introduction and operation of intermodal transport chains with certain economic measures. However, more intensive and rational use of intermodal transport technology involves the development of the network of logistics centers and intermodal transport terminal. In this regard, in addition to the terminal, which is the subject of this project and is a significant initiative and economic development of the transport system of Serbia, it is necessary to look at opportunities, requirements for development and justification of some other terminals, logistics centers and the formation of networks.

Here it is especially important to note that market analysis conducted in this project has shown the existence of potential flows for the implementation of intermodal transport technologies in the regions of Serbia, that do not gravitate greatly to a terminal in Belgrade. In addition to the potential of commodity flows, there is interest of certain business entities for the development of terminals and logistic centers. In order of effective and longterm development of intermodal transport and the creation of networks, it is necessary to do more research and define the optimum location of terminals and logistics centers.

\subsection{The Objectives of Development of a Network of Logistics Centers and Intermodal Transport Terminals}

Development of a network of logistics centers and intermodal transport terminals provides the ability to reduce logistics costs and improve the quality of logistics services. Summing goods and transport flows in terminals, logistics centers, has achieved the economies scale that justifies the application of environment friendly modes of transport (rail, river). On the other hand, tendency of business with small stocks, small and more frequent deliveries require development of intermodal logistics centers, as place of combination and synchronization costly, but fast and flexible road transport and transport modes, which are cheap, but slow and inflexible. In this sense, some of the basic aims of the network of logistics centers and intermodal terminals are: (Zečević, 2006)

- Rational and cost-effective investment in transport infrastructure for all modes of transport;

- Optimal reallocation of labor between different transport modes;

- Regulation of transport supply and demand through the coordination of the overall transport market in the state and region;

- Reduction and rational use of energy resources;

- Better use of transport means and systems through a coordinated issuance dispositions for the long and short distances transport;

- Expansion of markets for providers of transport and logistics services with greater cost-effectiveness;

- Development of modern intermodal transport technologies by establishing economic, technological and organizational co-operative links between all participants in the transport chain;

- Unburdening of urban areas from the heavy road transit and reducing urban traffic with enhanced servicing and supplying urban areas;

- Consolidation of flows and the development of city logistics concepts;

- Reduction of the negative impacts on the environment (air pollution, noise, etc.);

- Reduction of the time of distribution and transportation;

- Reduction of capital tied up in logistics systems; 
- Reduction of the total cost of distribution and logistics and their share in total costs of product which increases competitiveness of products on the market;

- Reduction of the total investments in logistics systems using concentration and cooperation;

- Reduction of the risk of investment in logistics systems;

- Possibility of giving a complete and complex logistics services;

- Development of the stock market models for the adjustment of supply and demand;

- Bid a variety of "value added" services;

- Create preconditions for technological quality inclusion in the international transport system, etc.

\subsection{Development Scenarios of the Network of Logistics Centers}

Key issues in intermodal transport are related to: the number of terminals (one or more terminals), the macro terminal location relative to the national transportation and economic space, micro location relative to urban areas, commercial and industrial complexes and transport infrastructure, or modality (unimodal, bimodal, multimodal).

The network of logistics centers and intermodal transport terminal in Serbia is defined multiple times in the past, but partial approach to solving the problem did not allow the achievement of specific effects and benefits provided by these systems. Many places, cities in Serbia were designated as potential sites for development of logistics centers. Some locations have reached a certain level of physical development of the terminal. Some sites have had the planning documentations, and some have neither the physical nor the planning elements of development (Vidović et al., 2011; Zečević et al., 2004).
Based on previous research and market analysis that was performed in the project "Facilitating Intermodal Transport in Serbia", the three scenarios are proposed for the development of a network of logistics centers and intermodal terminals in Serbia. The scenarios are defined to support the development of the network in phases. The first scenario involves development of core network, with a minimum number of terminals, whose primary function is involvement in regional, European intermodal transport system. The following scenarios represent expansion of the core network, first in the corridor, and then to the whole economic territory of Serbia.

Scenario 1: Involves development of two or three bimodal or multimodal terminals. These terminals would be the places of concentration of all intermodal flows in Serbia. Certainly, the scenario primarily involves orientation of the terminal on the corridors X and VII, and potential sites are in the larger economic centers (Belgrade, Niš and Novi Sad). The main advantage of this scenario is rationally investment in a smaller number of locations and concentration on the strong traffic flows and infrastructure. Lack of scenarios is the loss of potential intermodal flows from the other Serbian regions and economic centers, primarily South-Western Serbia.

Scenario 2: This scenario could be called a scenario Corridor. It includes development of four to six intermodal terminals at corridors VII and X (Fig. 1). The advantage of this scenario is the concentration of flows in the terminals located on the corridors. However, in this scenario there is a possibility of loss of intermodal flows from and to economic centers that are not on the corridor.

Scenario 3: This scenario involves development of the optimal number of 


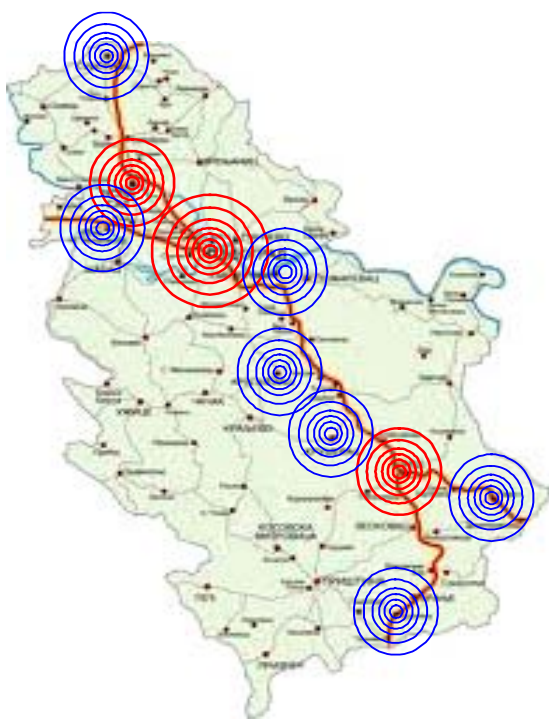

Fig. 1.

Scenario Corridor

intermodal terminals and larger number of the logistics centers throughout the territory of Serbia and could be called a scenario Network (Fig. 2). Locations for development of logistics centers and intermodal transport terminals should be sought in all major business centers in Serbia. The main advantage of this scenario is the coverage of the entire territory of Serbia with a choice of the optimal number of terminals and cargo flows that justify construction of the terminal. Of course, all terminals would not have the same structure, but in accordance with the requirements should be trained for the efficient handling of intermodal cargo units.

Each of the proposed scenarios has its own advantages and disadvantages, and the optimal solution of the network is the combination of the proposed scenarios. In the first phase, terminals should be developed on the strongest transport routes and, in accordance with the

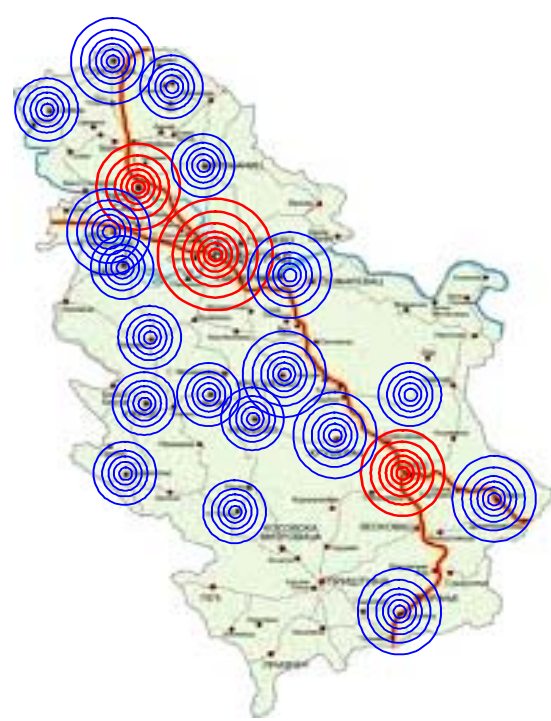

Fig. 2.

Scenario Network

interest of the economic system, should support the development of logistic centers that should be included in the network.

Development of logistics centers in any region of Serbia supports economic development of the region. Network scenario is a scenario of regional development of Serbia and it should be encouraged because it supports the economic development of cities.

Number and location of logistics centers and intermodal transport terminals is the subject research, which need to be implemented with the analysis of commodity flows and feasibility study for each potential site. A project should review the real flows, to define potential structure of the logistics centre or intermodal terminal, define micro location and connectivity to the transport infrastructure of certain types of transport and show the economic justification of development of terminal, logistics centre at a specific location. 


\section{Conclusion}

Trends and experiences clearly show the need, importance, objectives, directions, measures and solutions of development of logistics and intermodal transport. In developed countries, logistics and intermodal transport have long been the main factors of economic development, spatial connectivity and market integration. Inclusion of Serbia into the European transport and logistics system, international goods and transport flows is not possible without the use of intermodal technologies. Project and development of intermodal terminal in Belgrade is very important initiator of the development of the entire economic system in Serbia. In this regard, it is necessary to take a series of measures and recommendations that support the further development of logistics and intermodal transport technologies.

The effective development concept of logistics and intermodal transport requires the formation of a special research team consisting of the leading experts from science and practice and relevant providers and users of logistics services. This team should propose specific measures and define solutions and priorities in the process of development of logistics and intermodal transportation i.e. the network of logistics centers and intermodal transport terminals.

Except the plan of network development, it is necessary to develop a benchmarking system for intermodal terminals and logistics centers. A set of static and dynamic indicators of terminals operations should be defined with the aim of comparing, defining recommendations and establishing codes of best practice. In fact, measures and actions referred in this paper are designed to help long-term efficacy and growth of intermodal transport and logistics in Serbia. The Serbian government and relevant ministries have to participate and help these processes.

\section{References}

European Commission. 2007a. Freight Transport Logistics Action Plan. Brussels, COM(2007) 607 final.

European Commission. 2007b. The EU's freight transport agenda: Boosting the efficiency, integration and sustainability of freight transport in Europe. Brussels, COM(2007) 606 final.

European Commission. 2007c. An Action Plan for Freight Transport Logistics. Brussels.

European Commission. 2009a. A Sustainable Future for Transport: Towards an Integrated, Technology-led and Userfriendly System. Publications Office of the European Union, Luxembourg.

European Commission. 2009b. EU Energy and Transport in Figures - Statistical Pocketbook 2009. Brussels.

European Commission. 2011. Facilitating Intermodal Transport in Serbia. EU funded project under the frame of the IPA 2008 national program for Serbia. Belgrade.

Federal Ministry of Transport, Building and Urban Affairs. 2008. Freight Transport and Logistics Masterplan. Berlin.

Federal Ministry of Transport, Building and Urban Development. 2010. Freight Transport and Logistics Action Plan - Logistics Initiative for Germany. Berlin.

Vidović, M.; Zečević, S.; Kilibarda, M.; Vlajić, J.; Bjelić, N.; Tadić, S. 2011. The p-hub Model with Hub-catchment Areas, Existing Hubs, and Simulation: A Case Study of Serbian Intermodal Terminals, Networks and Spatial Economics. DOI: 10.1007/s11067-009-9126-7, 11(2): 295-314.

Zečević, S. 2006. Robni terminali i robno-transportni centri. University of Belgrade, Faculty of Transport and Traffic Engineering, (in Serbian).

Zečević, S.; Kilibarda, M.; Tadić, S. 2004. City logistika i robno transportni centri Beograda, Tehnika - Saobraćaj, 51(3): 215-222, (in Serbian). 


\section{RAZVOJ INTERMODALNOG TRANSPORTA I LOGISTIKE U SRBIJI}

\section{Snežana Tadić, Slobodan Zečević}

Rezime: Teretni transport i logistika igraju ključnu ulogu u ekonomskom i socijalnom smislu obezbeđujući konkurentnost, ekonomski rast i zapošljavanje. Intermodalni transport je dobio veću pažnju zbog problema zagušenja drumskih saobraćajnica, zaštite životne sredine i bezbednosti saobraćaja. Strateški značaj brzine, pouzdanosti i fleksibilnosti u lancu snabdevanja primorava firme da preispitaju tradicionalne logističke usluge. Kao posledica toga, interesovanje za istraživanje problema intermodalnog transporta i logistike raste. U cilju poboljšanja efikasnosti i održivosti teretnog transporta na području Evrope, Evropska komisija je pokrenula niz inicijativa, projekata, i definisala osnovne smernice razvoja intermodalnog transporta i logistike. U ovom radu dat je prikaz preporuka i mera u cilju razvoja intermodalnog transporta i logistike u Srbiji.

Ključne reči: logistika, intermodalni transport, logistički centar, mreža, razvoj. 